\title{
EFEKTIVITAS PENERAPAN MODEL KOOPERATIF TIPE NUMBERED HEDS TOGETHER (NHT) Dalam PEMBELAJARAN MATEMATIKA SISWA
}

\author{
Asmaul Husnah Amri \\ Program studi Pendidikan Matematika, Fakultas Keguruan dan Ilmu Pendidikan, Universitas \\ Pancasakti Makassar \\ e-mail: ammha2112@gmail.com
}

\begin{abstract}
ABSTRAK
Penelitian ini bertujuan untuk mengetahui bahwa model pembelajaran kooperatif tipe Numbered Heads Together (NHT) efektif diterapkan dalam pembelajaran matematika pada siswa kelas VII2 SMP Negeri 3 Tanasitolo Kabupaten Wajo yang ditinjau dari (1) ketuntasan belajar siswa, (2) aktivitas siswa dalam proses pembelajaran, (3) kemampuan guru dalam mengelola pembelajaran, dan (4) respon positif siswa terhadap pembelajaran. Pengambilan data dilakukan dengan menggunakan tes hasil belajar matematika, observasi aktivitas siswa dan guru dan angket untuk mengetahui respon siswa terhadap pembelajaran Hasil yang diperoleh adalah sebagai berikut: (1) Hasil belajar siswa yaitu dari 16 orang siswa sebagai subjek penelitian terdapat $15(93,75 \%)$ yang tuntas dan $1(6,25 \%)$ yang tidak tuntas secara perorangan, (2) Aktivitas siswa yang berkaitan dengan kegiatan pembelajaran dari keseluruhan aspek yang diamati, sebagian besar telah terlaksana, (3) Kemampuan guru dalam mengelola pembelajaran matematika melalui model pembelajaran kooperatif tipe Numbered Heads Together (NHT) secara umum berada pada kategori sangat baik, (4) Respon siswa terhadap pembelajaran kooperatif tipe Numbered Heads Together (NHT) dalam pembelajaran matematika pada umumnya memberikan tanggapan positif. Berdasarkan hasil penelitian maka model pembelajaran kooperatif tipe Numbered Heads Together (NHT) efektif diterapkan dalam pembelajaran matematika siswa.
\end{abstract}

Kata kunci: efektivitas; model pembelajaran Kooperatif tipe NHT; pembelajaran matematika

\section{ABSTRACT}

This study aims to determine that the Numbered Heads Together (NHT) cooperative learning model is effectively applied in mathematics learning in class VII2 students of SMP Negeri 3 Tanasitolo, Wajo Regency in terms of (1) student learning completeness, (2) student activity in the learning process, (3) the teacher's ability to manage learning, and (4) students' positive responses to learning. Data were collected by using mathematics learning outcomes tests, observing student and teacher activities and questionnaires to determine student responses to learning The results obtained were as follows: (1) Student learning outcomes, namely from 16 students as research subjects there were 15 (93,75\%) who completed and 1 (6.25\%) who did not complete individually, (2) Student activities related to learning activities from all aspects observed, most of them have been implemented, (3) The ability of teachers to manage mathematics learning through models Numbered Heads Together (NHT) cooperative learning is generally in the very good category, (4) Student responses to Numbered Heads Together (NHT) cooperative learning in mathematics learning generally give positive responses. Based on the results of the 
study, the Numbered Heads Together (NHT) cooperative learning model was effectively applied in students' mathematics learning.

Keywords: effectiveness; NHT cooperative learning model; mathematics learning

\section{A. PENDAHULUAN}

Proses pembelajaran matematika disekolah tidak selalu efektif. Salah satu aspek yang menyebabkan tidak efektifnya proses pembelajaran adalah ketuntasan belajar pada siswa. Adapun upaya yang dapat dilakukan untuk mengatasi kelemahan dalam pembelajaran matematika adalah pemilihan model pembelajaran yang tepat sehingga mampu melibatkan siswa secara aktif. Salah satu model pembelajaran yang melibatkan siswa secara aktif adalah model pembelajaran kooperatif.

Pembelajaran kooperatif merupakan model pembelajaran yang melibatkan siswa bekerja secara berkolaborasi untuk mencapai tujuan bersama. Model pembelajaran kooperatif tipe Numbered Heads Together (NHT) memiliki kelebihan, yaitu: setiap siswa menjadi siap semua, dapat melakukan diskusi dengan sungguh-sungguh, dan siswa yang pandai dapat mengajari siswa yang kurang pandai.

Adapun indikator yang dapat menunjukkan pembelajaran yang efektif yaitu:

1. Ketuntasan belajar

Ketuntasan belajar dapat dilihat dari hasil belajar yang telah mencapai kriteria ketuntasan belajar. Kriteria ketuntasan belajar dapat dilihat dari kriteria ketuntasan minimal perorangan dan klasikal ini yaitu:

1) Seorang siswa dikatakan telah tuntas belajar jika siswa tersebut telah memenuhi Kriteria Ketuntasan Minimal (KKM) yang ditentukan oleh sekolah yang bersangkutan.

2) Suatu kelas dikatan belajar tuntas secara klasikal apabila 85\% dari jumlah siswa keseluruhan telah mencapai skor ketuntasan minimal.

2. Aktivitas siswa

Aktivitas belajar matematika adalah proses komunikasi antara siswa dengan guru dalam lingkungan kelas sebagai hasil interaksi siswa dan guru atau siswa dengan siswa. Aktivitas siswa merupakan kegiatan atau perilaku yang terjadi selama proses belajar mengajar. Kegiatan-kegiatan yang dimaksud adalah kegiatan yang mengarah pada proses belajar seperti bertanya, mengajukan pendapat, mengerjakan tugas-tugas, dapat menjawab pertanyaan guru dan bisa bekerjasama dengan siswa lain, serta tanggung jawab terhadap tugas yang diberikan. Model pembelajaran kooperatif efektif diterapkan dalam hal aktivitas siswa jika 75\% dari aktivitas siswa tersebut sudah terlaksana.

3. Kemampuan guru mengelola pembelajaran

Proses pembelajaran dikatakan efektif jika dapat disimpulkan berjalan dengan baik. Penilaian terhadap kemampuan guru dalam mengelola pembelajaran dengan model pembelajaran kooperatif tipe Numbered Heads Together dibedakan atas empat, yaitu: (1) kurang baik, (2) cukup baik, (3) baik, (4) sangat baik. Hasil pengamatan diberikan pada setiap kategori pengamatan dengan memberikan tanda cek list $(\sqrt{ })$ pada kolom-kolom yang tersedia. 
4. Respon Siswa

Respon siswa yang dimaksudkan di sini adalah tanggapan siswa terhadap pembelajaran yang telah dilakukan, khususnya model pembelajaran yang digunakan.

Salah satu tipe pembelajaran yang biasanya digunakan dalam model pembelajaran kooperatif adalah Numbered Heads Together (NHT). Pemilihan model kooperatif tipe Numbered Heads Together (NHT) karena pembelajaran ini lebih banyak memberi kesempatan kepada siswa dalam berpikir, menjawab, dan saling membantu satu dengan yang lain dalam memecahkan masalah serta saling memotivasi untuk berprestasi dalam anggota kelompoknya.

Model pembelajaran kooperatif tipe Numbered Heads Together (NHT) menggunakan struktur empat fase, yaitu:

- Fase 1: Penomoran

Dalam fase ini, guru membagi siswa kedalam kelompok 3-5 orang dan kepada setiap anggota kelompok diberi nomor 1-5.

- Fase 2: Mengajukan pertanyaan

Guru mengajukan sebuah pertanyaan kepada siswa. Pertanyaan dapat bervariasi. Pertanyaan dapat amat spesifik dan dalam bentuk kalimat tanya.

- Fase 3: Berfikir bersama

Siswa menyatukan pendapatnya terhadap jawaban pertanyaan itu dan meyakinkan tiap anggota dalam timnya mengetahui jawaban tim.

- Fase 4: Menjawab

Guru memanggil suatu nomor tertentu, kemudian siswa yang nomornya sesuai mengacungkan tangannya dan mencoba untuk menjawab pertanyaan untuk seluruh kelas.

\section{B. METODE}

Jenis penelitian yang digunakan adalah penelitian pra eksperimen yang melibatkan satu kelas sebagai kelas eksperimen dengan tujuan untuk mengetahui efektivitas penerapan model pembelajaran kooperatif tipe Numbered Heads Together (NHT) dalam pembelajaran matematika.

Satuan eksperimen dalam penelitian ini adalah 1 kelas yang dipilih secara random dari 2 kelas. Dalam hal ini 2 kelas tersebut tersebar homogen (tidak terdapat pengklasifikasian antara siswa yang memiliki kecerdasan tinggi dengan siswa yang memiliki kecerdasan rendah).

Kelas yang telah terpilih sebagai satuan eksperimen, kemudian diberi perlakuan yaitu mengajar dengan menggunakan model pembelajaran kooperatif tipe Numbered Head Together (NHT).

Data hasil penelitian dikumpulkan dengan menggunakan instrumen penelitian berupa tes hasil belajar matematika, lembar observasi aktivitas siswa, dan angket respon siswa.

Data yang terkumpul selanjutnya diolah dengan menggunakan analisis statistika deskriptif. Analisis statistika deskriptif digunakan untuk mendeskripsikan atau memberi gambaran umum data yang diperoleh.

\section{HASIL DAN PEMBAHASAN}

Hasil analisis data hasil belajar matematika siswa setelah diterapkan model pembelajaran kooperatif tipe Numbered Heads Together berada pada kategori sangat rendah 
dengan persentase $100 \%$ atau 16 orang dari 16 orang siswa. Hal ini disebabkan karena siswa mengalami kesulitan dalam mengenai Unsur-unsur pada bentuk aljabar, misalnya menentukan variabel, konstanta, dan faktor, dan siswa berkesulitan dalam melakukan operasi hitung pada bentuk aljabar terutama pada opersi perkalian dan perpangkatan. Selain itu, keberanian siswa untuk menanyakan materi pelajaran yang belum dipahami kepada guru masih sangat kurang, serta kurangnya kepercayaan diri siswa untuk mengungkapkan pendapat, Sehingga pengetahuan siswa hanya terbatas pada apa yang dijelaskan oleh guru.

Sedangkan persentase nilai kognitif siswa setelah penerapan model pembelajaran kooperatif tipe Numbered Heads Together berada pada kategori sangat tinggi dengan persentase $6,25 \%$ atau 1 orang dari 16 orang siswa, 56,25\% atau 9 orang yang berada pada kategori tinggi, $31,25 \%$ atau 5 orang yang berada pada kategori sedang, $0 \%$ yang berada pada kategori rendah dan $6,25 \%$ atau 1 orang yang berada pada kategori sangat rendah. Ini berarti siswa yang berada pada kategori sangat rendah setelah diterapkan model pembelajaran kooperatif tipe Numbered Heads Together lebih sedikit dibanding dari kategori sangat rendah sebelum diterapkan model pembelajaran kooperatif tipe Numbered Heads Together. Hal ini disebabkan dengan pengetahuan siswa terhadap materi yang diajarkan sudah lebih dipahami. Selain itu, keberanian siswa untuk mengajukan pertanyaan yang berkaitan dengan materi yang belum dipahaminya juga meningkat. Dengan membandingkan persentase tersebut, berarti pembelajaran dengan menggunakan model pembelajaran kooperatif tipe Numbered Heads Together efektif digunakan dalam pembelajaran matematika.Hasil pengamatan menunjukkan bahwa ketuntasan belajar siswa mencapai 15 orang dari 16 orang siswa atau sekitar 93,75\% siswa yang tuntas secara perorangan.

Hasil pengamatan terhadap aktivitas siswa dalam pembelajaran kooperatif tipe Numbered Heads Together menunjukkan bahwa siswa tidak canggung dalam bekerja sama menyelesaikan suatu masalah maupun pada saat ditunjuk untuk mempresentasikan hasil kerja kelompoknya, saling memberi dan menerima pendapat, bagi siswa yang merasa mampu akan memberikan masukan yang berarti bagi teman kelompoknya pada saat melakukan diskusi maupun mengemukakan pendapat, saling memberikan dukungan serta menghargai pendapat orang lain. Aktivitas siswa yang berkaitan dengan kegiatan pembelajaran dari keseluruhan aspek yang diamati, secara keseluruhan berada pada kategori baik.

Berdasarkan hasil analisis respon siswa diperoleh bahwa lebih dari 90,00\% siswa memberikan respon positif terhadap pelaksanaan pembelajaran kooperatif tipe Numbered Heads Together dalam pembelajaran matematika. Hal ini berarti bahwa pembelajaran matematika dengan menggunakan model pembelajaran kooperatif tipe Numbered Heads Together dapat mengakibatkan adanya perubahan pandangan siswa terhadap matematika dari matematika yang menakutkan dan membosankan menuju matematika yang menyenangkan sehingga keinginan untuk mempelajari matematika semakin besar.

Kemampuan guru dalam mengelola pembelajaran matematika melalui model pembelajaran kooperatif tipe Numbered Heads Together secara umum berada pada kategori sangat baik. Hal ini dapat dilihat dari rata-rata kategori aktivitas guru pada pertemuan terakhir mencapai 3,50 $\leq$ nilai $<4,00$. Respon siswa terhadap pembelajaran kooperatif tipe Numbered Heads Together dalam pembelajaran matematika pada umumnya memberikan tanggapan positif. Kemudian untuk melihat persentase pencapaian keefektifan model pembelajaran kooperatif tipe Numbered Heads Together dapat dilihat pada tabel berikut; 
Tabel 1 Pencapaian keefektifan model pembelajaran kooperatif tipe Numbered Heads Together

\begin{tabular}{clc}
\hline No. & \multicolumn{1}{c}{ Kriteria Keefektifan } & Kesimpulan \\
\hline 1. & Hasil belajar siswa & Tuntas \\
\hline 2. & Aktivitas siswa & Efektif \\
\hline 3. & Respon Siswa & Positif \\
\hline 4. & $\begin{array}{l}\text { Kemampuan guru } \\
\text { mengelola pembelajaran }\end{array}$ & Efektif \\
\hline
\end{tabular}

\section{PENUTUP}

\section{Kesimpulan}

Adapun kesimpulan yang dapat diambil dari hasil penelitian ini adalah model pembelajaran kooperatif tipe Numbered Heads Together efektif diterapkan dalam pembelajaran matematika siswa. Hal ini berdasarkan:

a. Ketuntasan hasil belajar siswa sebelum penerapan model pembelajaran kooperatif tipe Numbered Heads Together (NHT) yaitu dari 16 orang siswa sebagai subjek penelitian terdapat $16(100 \%)$ yang tidak tuntas secara perorangan, dan 15 $(93,75 \%)$ yang tuntas dan $1(6,25 \%)$ yang tidak tuntas setelah penerapan model pembelajaran kooperatif tipe Numbered Heads Together. Ini berarti siswa di Kelas $\mathrm{VII}_{2}$ telah mencapai ketuntasan secara klasikal dimana ketuntasan klasikal tercapai apabila minimal $85 \%$ siswa di kelas tersebut telah mencapai skor ketuntasan minimal.

b. Aktivitas siswa

Rata-rata persentase aktivitas siswa terhadap pelaksanaan pembelajaran kooperatif tipe Numbered Head Together (NHT) yaitu 50,50\%.Sesuai dengan indikator aktivitas siswa yaitu siswa dikatakan aktif jika sekurang-kurangnya $75 \%$ siswa terlibat aktif dalam pembelajaran, sedangakan dari hasil pengamatan ratarata persentase aktivitas siswa hanya $50,50 \%$ maka aktivitas siswa belum mencapai kriteria aktif

c. Kemampuan guru dalam mengelola pembelajaran matematika melalui model pembelajaran kooperatif tipe Numbered Heads Together secara umum berada pada kategori sangat baik. Respon siswa terhadap pembelajaran kooperatif tipe Numbered Heads Together dalam pembelajaran matematika pada umumnya memberikan tanggapan positif.

d. Respon siswa terhadap pembelajaran kooperatif tipe Numbered Heads Together (NHT) dalam pembelajaran matematika pada umumnya memberikan tanggapan positif.

\section{Saran}

Berdasarkan hasil penelitian ini, peneliti menyarankan:

a. Pembelajaran matematika melalui penerapan model pembelajaran kooperatif tipe Numbered Heads Together layak dipertimbangkan untuk digunakan di sekolah.

b. Guru dapat menerapkan model pembelajaran kooperatif tipe Numbered Heads Together untuk mencapai proses pembelajaran yang lebih efektif dengan memperhatikan kekurangan-kekurangan pada penelitian ini. 


\section{DAFTAR PUSTAKA}

Hamzah \& Nurdin. 2011. Belajar dengan Pendekatan PAIKEM. Jakarta: Bumi Aksara.

Lisna. 2012. Efektivitas Pembelajaran Matematika melalui Model Pembelajaran kooperatif tipe Two Stay Two Stray pada Siswa Kelas VII 4 SMP Negeri 4 Pallangga Kabupaten Gowa. Skripsi tidak diterbitkan. Makassar: Universitas Muhammadiyah Makassar.

Setyosari Punaji. 2010. Metodologi Penelitian Pendidikan dan Pengembangan. Yogyakarta: PT Bumi Aksara.

Slameto. 2003. Belajar dan Faktor-Faktor yang Mempengaruhinya. Jakarta: PT Rineka Cipta.

Sukmadinata, Nana syaodih. 2012. Metode Penelitian Pendidikan. Bandung: PT Remaja Rosdakarya.

Suprijono, Agus. 2012. Cooperatif Learning. Surabaya: Pustaka Pelajar

Syafrullah. 2012. Efektivitas Pembelajaran Matematika melalui Model Pembelajaran kooperatif tipe Numbered Heads Together pada Siswa Kelas VII SMP Negeri 3 Camba Kabupaten Maros. Skripsi tidak diterbitkan. Makassar: Universitas Muhammadiyah Makassar.

Tim Kreasi Bahasa. 2005. Kamus Bahasa Indonesia: Kreasi Media.

Tiro, Muhammad Arif. 2007. Dasar-dasar Statistika. Makassar: Universitas Negeri Makassar.

Trianto. 2007. Model-Model Pembelajaran Inovatif Berorientasi Konstruktivistik. Jakarta: Prestasi Pustaka Publisher. 